\title{
Does School/Site Based Management (SBM) in Japan Achieve its Policy Purposes? \\ A Policy Analysis of Japanese Education Reform RegardingSchool Advisors and School Management Councils
}

\author{
Jun Hirata (Faculty of Education, Hirosaki University, Japan)
}

\begin{abstract}
The purpose of this paper is to analyze decentralized education reform in Japan in terms of School/Site-Based Management (SBM). In the literature, SBM embraces two major elements, namely, the devolution of decision-making authority to the individual school level and Shared Decision-Making (SDM). In Japan, school advisors and school management councils have been established with similar purposes with SBM since 2000. However, because the decisionmaking authority is not sufficiently devolved to each school and many groups of stakeholders are not significantly involved in decision-making processes, a SBM form of school governance has not been realized in Japan.
\end{abstract}

\section{Résumé}

Cet article a pour but d'analyser la réforme de décentralisation de l'éducation au Japon en termes de l'Administration basée sur l'école ou le site (SBM). Dans la littérature, la SBM se comprend de deux éléments: la dévolution au niveau de chaque école les droits d'exécuter des décisions et la politique des décisions partagées (SDM). Au Japon, les postes de conseillers et les conseils d'administration ont été établis depuis l'an 2000. Et pourtant, parce que les instances ne sont pas assez engagées dans le processus décisionnel, une forme de gouvernance des écoles selon la SBM n’a pas pu se réaliser au Japon.

\section{Introduction}

The devolution of authority to individual schools has been implemented in many parts of the world. This form of school governance is called "School/Site-Based Management (SBM)" in North America, and "Local Management of Schools (LMS)" in England. The rationale of this sort of reform is that those most closely affected by school-level decisions, such as teachers, students and parents, ought to play a significant role in making decisions (Wholstetter \& Buffett, 1991; Murphy \& Beck, 1995). Also in Japan, the expansion of the schools' discretion and authority is a centrepiece of the ongoing education reform. According to Ogawa (2000), expanding the areas for which schools have discretion shares some conditions and assumptions with SBM. In order to achieve this reform goal, two systems have been put into practice, namely, the school advisor system and the 
school management council system, under the name of "Opened-Management of Schools (OMS)".

The purpose of this study is to analyze these two systems in terms of SBM and to uncover whether these strategies can achieve OMS and SBM. In this paper, first of all, literature concerning SBM will be reviewed and analytical perspectives for the study will be set. Secondly, the policy of OMS will be described especially focusing on school advisors and school management councils. In the third place, these two strategies for accomplishing an OMS form of school governance will be analyzed in terms of the concept of SBM. Lastly, it will be mentioned whether school advisors and school management councils lead schools to successful SBM schools and how they can achieve this reform goal.

\section{Literature Review and Analytical Perspectives}

In this section, the literature concerning SBM is reviewed. Analytical perspectives for this study will be embedded in the review of literature.

\section{Implications and Major Elements of SBM}

The meaning of SBM includes an array of terms, such as "school-site autonomy, school-site management, school-centered management, decentralized management, school-based budgeting, school-site lump sum budgeting, responsible autonomy, shared governance, the autonomous school concept, school-based curriculum development and administrative decentralization" (Clune \& White, 1988, p. 3; cited in Murphy \& Beck, 1995, p. 12). Although SBM has a broad range of meanings and implications, Herman (1990) defines SBM simply as "A structure and process which allows greater decision-making power related to the areas of instruction, budget, policies, rules and regulations, staffing, and all matters of governance; and a process which involves a variety of stakeholders in the decisions related to the local individual school building” (p. 3).

The basic rationale of SBM is that those most closely affected by schoollevel decisions, such as teachers, students and parents, ought to play a significant role in making decisions (Wohlstetter \& Buffett, 1991; Murphy \& Beck, 1995). The following aspects are indicated to support this rationale. Stakeholders in the school system have the right and responsibility to get involved in the decisionmaking (Burke, 1992; Murphy \& Beck, 1995). Students, parents, school staffs and communities have unique needs, and these needs can best be identified and addressed by themselves (Jewell \& Rosen, 1993; Murphy \& Beck, 1995). The school is the fundamental decision-making unit within the educational system (Guthrie, 1986; Murphy \& Beck, 1995), and schools have to be given the capacity to identify and respond to student needs (Stevenson, 1990; Murphy \& Beck, 1995). In this respect, Burke (1992) asserts that "imposed educational decisions disempower certain categories of stakeholders” (p. 39; cited in Murphy \& Beck, 1995, p. 22). Lastly, "those actors with the best information about a particular subject should have the discretion to make decisions about that subject" (Hannaway, 1992, p. 2; cited in Murphy \& Beck, 1995, p. 22), and "the people in 
closest contact with students are the ones most likely to make good decisions" (Hill \& Bonan, 1991, p. 6; cited in Murphy \& Beck, 1995, p. 22).

Two major elements of SBM can be extracted from these aspects to support a SBM form of school governance: the devolution of decision-making authority to the level of individual schools; and participatory decision-making or Shared Decision-Making (SDM).

The perspective of the devolution of decision-making authority arose from critical problems of the centralized education system. Brown (1990) points out that in a centralized system persons responsible for the education of students have little authority to control educational resources, while persons not responsible for students have authority in controlling resources for schools. As a result, the following problems arise. First, schools face a lack of flexibility. School staff on site has little control over resources deployed to their schools in that they do not make key decisions about equipment, personnel kinds or quality, or maintenance of their buildings. However, they are considered responsible for the education of the students under their care. In addition, the central office personnel are perceived in control of district budgets, most of which affect schools directly. They are perceived as having the authority to allocate resources for students but they do not have responsibility for their education, where the disparity between the authority and the responsibility would be found. As a consequence, individual schools resort to spending practices which appear inefficient and they are required to lobby for resources, an outcome of which is that more resources are directed to some schools than others (Brown, 1990).

In order to overcome these problems, advocates of SBM insist that "activities that directly impact students on a day-to-day basis must be determined as close to the student as possible" (Candoli, 1991, p. 40; cited in Murphy \& Beck, 1995, p. 21). Those persons closest to the students should make decisions about the educational programs, such as curriculum, instruction, and the organization of time, people, facilities, and other resources, for those students (Mojkowske \& Fleming, 1988; Murphy \& Beck, 1995), because those closest to a situation are uniquely positioned to address their needs and the needs of their students (Murphy \& Beck, 1995). In terms of flexibility, above all, Brown (1990) found, in his qualitative research concerning decentralization in Alberta, British Columbia and Cleveland, that SBM schools have more flexibility than schools under centralized education system.

As to participatory decision-making, Mintzberg (1989) views decentralization or SBM as the extent which power is dispersed among many individuals in an organization. Wood (1984) asserts that "participatory decisionmaking is a collaborative approach in which superordinates and subordinates (and community members) work together as equals in an attempt to identify, analyze, and solve problems that face the organization" (p. 63). Therefore, in a SBM form of school governance, the decision-making authority is expected to be shared with many stakeholders, such as principals, teachers, students, parents, and the community members. 


\section{Factors Leading to Successful and Unsuccessful SBM}

Although the SBM form of school governance has advantages mentioned above, SBM itself cannot accomplish its policy aims. In the literature, some factors leading to unsuccessful and successful SBM have been pointed out.

Wohlstetter (1995) found, in her qualitative research held in some school districts in the United States, Canada and Australia, that SBM fails because it is adopted as an end in itself. "As a form of governance, SBM will not in itself generate improvement in school performance. Instead, SBM is simply a means through which school-level decision makers can implement various reforms that can improve teaching and learning” (Wohlstetter, 1995, p. 23). Weiss \& Cambone (1994) also found, in their research on high school principals' perception on a Shared Decision-Making (SDM) form of school governance, that SDM does not lead to change by itself. They indicated that it can become merely a system for venting grievances, dealing with minor annoyances, or even transferring to the team unpleasant responsibilities that administrators are reluctant to shoulder alone, such as deciding where the budget should be cut. In order to make SBM successful, it is necessary to clarify the connection between SBM and reform agendas such as curriculum and instruction, and to focus on creating strategies to deploy this connection.

Wohlstetter (1995) notes from her research mentioned above that in unsuccessful SBM schools, principals work from their own agendas. "In struggling schools, many principals were perceived as too autocratic by their staff, who reported that their principals appeared to have agendas of their own and to dominate all decisions” (Wohlstetter, 1995, p. 23).

SBM schools tend to be unsuccessful where decision-making power is lodged in a single council. "Schools that were struggling with SBM tended to concentrate power in a single school council that often was composed of a small group of committed teachers who were painfully aware that they did not have board representation. These councils tended to get bogged down in establishing power relationships" (Wohlstetter, 1995, p. 23). It is crucial to make sure that a wide range of stakeholders participates in school management and that their voice is equally respected.

Furthermore, SBM tends to fail when business proceeds as usual. Because SBM is a time-consuming and complicated process that places high demands on all individuals involved, SBM cannot be put in place successfully with just average levels of commitment and energy (Wohlstetter, 1995). As Starratt notes (1996), SBM requires participants to spend more time on school council deliberations through their collaboration, and they sometimes resist such initiatives. However, Hallinger, Murphy \& Hausman (1993) found, in their research on principals' and teachers' perceptions on SBM in the state of Tennessee, that although decision-making is slowed down as more people become involved, the extra time devoted to decision-making results in better decisions that are also more likely to be successfully implemented.

On the other hand, in order to overcome these factors which lead to unsuccessful SBM, some strategies have been noted. First of all, Wohlstetter 
(1995) suggests that schools establish many teacher-led, decision-making teams to be successful SBM schools. These teams should be designed to facilitate interaction across the traditional boundaries of department and grade levels. In her analysis of the research concerning SBM mentioned above, subcommittees of the school council that are open to interested teachers or parents are crucial. "The most effective school councils were those that served largely to coordinate and integrate the activities of the various decision-making groups operating throughout the school” (Wohlstetter, 1995, p. 184). Epstein (1995) also indicates that creating action teams, comprised of teachers, parents, students and other school staff, is important to make SBM effective and to promote the partnership between the school, families and the community.

It is also crucial to create a well-developed system for sharing schoolrelated information with a broad range of participants. Wohlstetter (1995) suggests from her research results that most successful SBM schools were systematic and creative in their efforts to communicate with parents and the community, and they used many communication mechanisms to share information, such as annual parent and community survey, regular dissemination to parents of data on daily attendance and tardiness, parent/teacher conferences, and school newsletters. It is important to use the data collected through these systems in order to analyze the needs of parents and students, and to relate their analysis to the strategies for improving schools.

Lastly, it is important to focus on continuous improvement with schoolwide training in functional and process skills and in areas related to curriculum and instruction. Wohlstetter (1995) found in her study that in schools where SBM worked, staff members participated in training opportunities for developing professional skills as well as decision-making skills. These opportunities provide teachers with a shared knowledge base. Also, training in the area of decisionmaking skill development should be opened to those who were interested, not limited to members of some bodies. School councils or subcommittees in these schools, if they exist, assess professional development needs, plan and coordinate activities to meet those needs. In order to make SBM work, it is important that these activities are used strategically and are deliberately tied to the school's reform objectives.

\section{“Opened-Management of Schools” in Japan}

In this section, the current education reform in Japan will be reviewed, especially focusing on decentralization. After overseeing the ongoing decentralization reform, two strategies instituted at the national level to promote OMS in Japan will be explained, namely, the school advisor system and the school management council system.

\section{Decentralization of Educational Administration}

Japan is riding the wave of decentralization and deregulation in many aspects of public administration, which includes educational administration. Because of this 
trend, many agendas in education are being decentralized from the national level to the local government level, and ultimately, to the individual school level.

The impetus of the current decentralization of educational administration was a recommendation by Chuo Kyouiku Shingikai (the Central Council for Education), an advisory council to the Minister of Education. The Central Council for Education issued its report in 1998: Kongo no Chihou Kyouikugyousei no Arikata ni tsuite (On Prospects of Local Educational Administration), and recommended a review of educational administration in terms of the role distribution between the national government, the prefectural governments, and the municipal governments in educational administration. It also recommended a review of the system of Boards of Education; the establishment of independence and autonomy of schools; and a review of the role of the Boards of Education in the improvement of communities' educational function and community development. The term review in this report generally means to devolve the authority and responsibility from the upper levels of educational administration to the lower levels, and ultimately, to the individual school level. Following this report, many amendments were made in educational laws and regulations in the pursuit of a more decentralized educational administration. By giving more authority to each school, the policymakers aim at achieving independent and autonomous school management and educational activities characteristic of the environment surrounding each school.

\section{“Opened-Management of Schools”}

The devolution of authority to the individual school level enables schools to implement educational activities based on needs specific to each school. Related to the devolution of power, a major agenda in the current education reform in Japan is expressed as Hirakareta Gakkou Zukuri (Opened-Management of Schools: OMS). OMS means that school management is opened to the community in order to develop a partnership with parents and the community, to achieve an independent and autonomous school management system, and to put into practice education that is more relevant to the community.

The Central Council for Education (1998) asserted the importance of OMS in its report mentioned above, On Prospects of Local Educational Administration in 1998, and its intention of opening schools to the community means to obtain input and information from outside the school in order to reflect the community's educational needs. In addition, OMS requires schools to provide parents and community residents with information about the education of the children, which leads to increasing accountability of schools. In this situation, schools need a system to gain input from the community and to provide information back to the community. After this report, in 2000, the school advisor system was $n$ introduced to facilitate an OMS form of school governance.

\section{The School Advisor System}

In 2000, the Regulation for the Implementation of the School Education Act was amended so that the school could have advisors appointed by the Board of 
Education from the community based on the principal's recommendation. The school advisor system is intended to contribute to the following aspects of school management: reflect the educational needs of parents and the community on school activities; obtain cooperation from parents and the community; and hold schools accountable by providing parents and the community with information on school management (Sato, 2000).

Hishimura (2000) points out some important aspects to understand the school advisor system. First, although school advisors have legal status, schools are not forced to have school advisors. The concrete issues such as the number of school advisors and their term of office depend on the founders of the schools (Boards of Education for public schools) in order to make a flexible system based on the situation of the community and the school. School advisors are expected to address their opinions about school administration in response to requests from principals, where each school advisor provides her/his own opinions under her/his own responsibility, and not the advisory body as a whole. The school advisor system is based on principals' authority and responsibility for school administration; therefore, although principals can ask advisors for opinions and advice, the final decisions are made by the principals based on their own authority and responsibility. Teachers and students are not assumed to be school advisors. Personnel of the Boards of Education cannot be advisors because they are on the side of establishing and operating the schools.

According to the Ministry of Education, as of July 1, 2005, 32.2\% of public kindergartens, $83.7 \%$ of public elementary schools, $84.5 \%$ of public junior high schools, and $91.0 \%$ of public high schools, in total $78.4 \%$ of public schools had adopted the school advisor system $\left(\mathrm{MEXT}^{1}, 2006\right)$.

\section{"Community Schools" and "School Management Councils"}

As another strategy for OMS, the Local Educational Administration Act was partly amended in June 2004, in which school management councils were instituted at the national level. The impetus for instituting school management councils was the recommendation by Kyouiku Kaikaku Kokumin Kaigi (the National Conference for Education Reform), which was organized as a private advisory body for the then Prime Minister in 2000. This conference issued its final report, Kyouiku wo kaeru 17 no Teigen (17 Recommendations to change Education), in December 2000, and it suggested the establishment of a new type of public school by involving parents and community residents in school management.

This recommendation was taken over by some other governmental councils and this issue continued to be discussed. In March 2004, the Central Council for Education issued its report, Kongo no Gakkou no Kanri Un-ei no Arikate ni tsuite (On Prospects of School Management). The report recommended that a new type of public school be established, where parents and community residents could become involved in school management with a certain authority and responsibility; these schools are called community-managed schools or community schools. The report also pointed out that as a system of guaranteeing 
the involvement of parents and community residents in school management, it was necessary for school management councils to be established to discuss the management of community schools. In response to this report, in June 2004, a chapter concerning community schools and school management councils was added to the Local Educational Administration Act. This system came into being in September 2004.

In terms of the report of the Central Council for Education, the provisions of the Act, and the Ministerial notification on the implementation of the amendment, some characteristics of community schools and school management councils are indicated out as follows:

School management councils are established in schools designated to be community schools by Boards of Education as organizations to discuss the management of the designated schools.

Members of school management councils are appointed by Boards of Education from among parents of students, community residents, and persons that Boards of Education think are appropriate. Principals and school staff can be members on the basis of the determination of Boards of Education.

The number, composition, appointment, dismissal, and term of office of members, and agenda items and some other items necessary for the management of school management councils are provided in regulations of Boards of Education.

Principals of the designated schools shall make basic plans on curriculum and some other issues provided in regulations of Boards of Education and get approval from school management councils in school management. School management councils can present opinions to those who appoint (they are usually Boards of Education) staff about the appointments of staff and other staffing policies. Those who appoint staff shall take the opinions seriously, and acknowledge them unless there is a valid reason not to do so.

According to the Ministry of Education, 34 public schools have been designated as be community schools as of July $1^{\text {st }}$, 2005. 19 public schools are planning to be community schools during the 2005 school year. 40 public schools consider that they will become community schools during the 2006 school year. 131 public schools are under discussion to become community schools after the 2006 school year (MEXT, 2006). The Ministry of Education expects the establishment of community schools ${ }^{2}$ to be more promoted (MEXT, 2006).

\section{Analysis:}

Have School Advisors and School Management Councils achieved a SBM Form of School Governance?

From the literature review, some aspects which shape the concept of SBM and lead to successful and unsuccessful SBM have been discussed. In this section, an analysis ofthe function of school advisors and school management councils will be conducted in terms of those viewpoints. 
Decentralization of the Decision-Making Authority

As mentioned above, decentralization of the decision-making authority is a major element of SBM. Elements of decentralized education reform in Japan will be discussed below.

Policymakers aim at devolving decision-making authority and responsibility to individual schools. However, many principals actually do not feel that they have obtained more authority and responsibility since the start of the current decentralization reform. For instance, according to research by Kono conducted in the fall of 2001 , only $10 \%$ of principals in public elementary and junior high schools in Japan responded that they felt that the authority for the school budget had actually been devolved (Nippon Kyoiku Shinbun, 2003). It is also reported that $77 \%$ of directors of Boards of Education think that schools' discretion on school budget should be expanded (Nippon Kyoiku Shinbun, 2005). Furthermore, the staffing policy is still in the hands of Boards of Education for the most part, and principals have little influence over it. Based on these facts, it is noted that, as a whole, Japanese schools have not adopted a SBM form of school governance yet, although it could be said that SBM reform is still ongoing, and not completed. Therefore, school advisors do not make any difference in how much authority is devolved to the individual school level.

On the other hand, it is suggested through the legislation that community schools should be provided more authority, and Ministerial notification of community schools recognizes its necessity. However, Ministerial notification also points out that they should try to expand the authority of ordinary schools as well. In this sense, it is not clear whether the Ministry is attempting to differentiate community schools from ordinary schools by giving more authority to community schools.

In another aspect, according to the Local Educational Administration Act, the designation of community schools and the appointment of members are in the hands of Boards of Education. Also, when principals' opinions collide with those of school management councils and the disagreement continues, it is the Boards' determination to revoke the designation of community schools to avoid problems. Therefore, ultimately, what decisions school management councils make depends on the policy of Boards of Education on how much authority is devolved to the individual schools.

Shared Decision-Making: Who eventually participates in decision-making processes?

Wohlstetter (1995) asserted that SBM fails when principals start to reform their own agendas, which indicates that another major element of SBM is SDM. In the school advisor system, the decision-making authority is not assumed to be shared between principals and advisors. Rather, the school advisor system is based on principals' authority for school administration. Therefore, although principals can ask for advisors' opinions, the final decisions are made by the principals themselves based on their own determination. Even when principals do not adopt advisors' opinions, principals are not obligated to report reasons for their 
decisions to advisors. In this senses the school advisor system is not based on the concept of SDM.

In community schools, when a principal decides a basic school policy at the beginning of the school year, she/he has to get approval from the school management council. School management councils can provide principals with their opinions on any issue related to the school. Furthermore, school management councils can state their opinions on staffing to Boards of Education, and the Boards are required to respect the opinions and attempt to achieve the intention of school management councils unless there is a reasonable reason not to do so. Considering these aspects, it is possible to say that the school management council system has adopted the concept of SDM.

On the other hand, in appointing the members of school management councils, it is not anticipated that council members will be elected by community residents. It is Boards of Education that appoint council members, where Boards' decisions on membership could be arbitrary and it is not guaranteed that opinions of council members really represent educational needs of the community.

Wohlstetter (1995) also suggests that it is crucial to establish many teacher-led decision-making teams to be successful SBM schools and that SBM fails when decision-making power is lodged in a single council. On the other hand, in the ongoing education reform in Japan, teachers tend to be excluded from the decision-making processes. Every school in Japan has traditionally had a teacher council as a collective body among the teachers in the school. Although teacher councils did not have any legal status, they were eventual decision-making bodies at schools, or at least had great influence on the decision-making processes. However, the Regulation for the Implementation of the School Education Act was amended in 2000, which provides teacher councils with legal status as supporting bodies for principals. It makes it clear that the decision-making authority is held by only principals, and teachers are to play a role only to support principals' school administration on the basis of decisions made by principals.

In the school advisor system, teachers are not assumed to be advisors because a purpose of the system is to obtain opinions from outside the school. In community schools as well, teachers are not involved in school management councils according to the national policy. Therefore, the devolution of the decision-making authority to the level of individual schools eventually means that principals' control over teachers is strengthened. It has also been pointed out that gaining opinions from outside the school means that teachers' influence on decision-making relatively declines. To sum up, the current education reform in Japan disempowers teachers.

\section{Conclusion}

OMS has been introduced to accomplish a more open form of school management for the community. Therefore, it is said that OMS shares some conditions and assumptions with SBM, whose major elements are the devolution of the decisionmaking authority and SDM. The school advisor system is the first legislation for 
establishing a system to open schools to the community (Ojima, 2001). Community schools and school management councils are expected to promote a more open form of school management. However, literally interpreting governmental documents, these strategies do not necessarily lead to successful SBM.

It is doubtful whether school advisors and school management councils can really "open" schools to stakeholders, such as parents, the community residents and students (Urano, 1998) because school advisors and members of school management councils do not necessarily represent stakeholders' opinions while Boards of Education maintain the discretion on membership in both systems. Wohlstetter (1995) suggests from her research results that most successful SBM schools were systematic and creative in their efforts to communicate with parents and the community, and they used many communication mechanisms to share information. On the other hand, Fukuoka (2006) finds in her research on the function of school advisors that most parents feel that they are not asked opinions by advisors in any form and even do not know that school advisors exist in their schools. It is also pointed out that advisors take such perceptions of parents as a matter of fact, but that they do not take any action to overcome the sort of problems parents have indicated.

With regard to school management councils, because the number of community schools is extremely small, it is too early to evaluate their function on the basis of empirical data. However, based on governmental documents, it is quite possible for school management councils to confront the same sort of obstacles with school advisors because the decision-making authority is not sufficiently devolved and decision-making processes are not necessarily shared among stakeholders as was noted in the last section. Therefore, in conclusion, school advisors and school management councils, which are established in the pursuit of OMS, do not necessarily achieve the policy purposes of SBM.

On the other hand, beyond the national policy, even before school advisors were instituted in 2000, some schools had voluntarily established what is called school councils, which are collective bodies involving administrators, teachers, parents, community residents and students. It is reported that some of these voluntarily established school councils work well. Although these collective bodies do not have decision-making authority, principals cannot just ignore the consequences of deliberations in such bodies because representatives are elected by members of each category of stakeholders, which indicates that they are involved in decision-making processes and that SDM is accomplished, although the decision-making authority is not sufficiently devolved to these schools as well. As a result, representatives feel that forming agreements among stakeholders is important in the school council deliberations, and that they are actually empowered in the processes (Hirata, 2004). The Ministry of Education is expected to learn from these successful cases and use these examples to bring about improvement in the function of school advisors and school management councils. 


\section{Notes:}

1. The office in charge of education at the national level in Japan is officially named the Ministry of Education, Culture, Sports, Science and Technology, which is abbreviated MEXT.

2. In Japan, 5,546 public kindergartens, 22,856 public elementary schools, 10,238 public junior high schools, and 4,082 public high schools exist in 2005 (MEXT, 2005)

\section{References}

Brown, D. J. (1990). Decentralization and school-based management. London: The Falmer Press.

Burke, C. (1992). Devolution of responsibility to Queensland schools: Clarifying the rhetoric critiquing the reality. Journal of Educational Administration, 30 (4), 3352.

Clune, W. H. \& White, P. A. (September 1988). School-based management: Institutional variation, implementation, and issues for further research. New Brunswick, NJ: Rutgers University, Eagleton Institute of Politics, Center for Policy Research in Education.

Candoli, I. C. (1991). School system administration: A strategic plan for site-based management. Lancaster, PA: Technomic.

Epstein, J. (May 1995). School/family/community partnership. Phi Delta Kappan, 701-712.

Fukuoka, Y. (2006). Gakko hyogin wa "Hirakareta gakko Zukuri” wo sokushin suru noka? (Do school advisors facilitate "Opened-Management of Schools?). Unpublished master dissertation. Hirosaki: Hirosaki University.

Guthrie, J. W. (December 1986). School-based management: The next needed education reform. Phi Delta Kappan, 68 (4), 305-309.

Hallinger, P., Murphy, J. \& Hausman, C. (1993). Conceptualizing school restructuring: Principals' and teachers' perceptions. In C. Dimmock (Eds.), School-based management and school effectiveness (pp. 22-40). London: Routledge.

Hannaway, J. (March 1992). Decentralization in education: Technical demands as a critical ingredient. (ERIC Document Reproduction Service No. ED 345 362)

Herman, J. J. (1990). School-based management. Instructional Leader, III (4), Texas Elementary Principals and Supervisors Association, 1-4.

Hill, P. T. \& Bonan, J. (1991). Decentralization and accountability in public education. Santa Monica, CA: Rand.

Hirata, J. (2004). Do school councils empower students? Two Japanese case studies. Unpublished doctoral dissertation. Toronto: University of Toronto.

Hishimura, Y. (May 2000). Gakkou hyougiin seido wo kangaeru (Thinking of the school advisor system). Kyoushoku Kenshu (Teacher Study and Training), 20-21.

Jewel, K. E. \& Rosen, J. L. (April 1993). School-based management/shared decisionmaking: A study of school reform in New York City. Paper presented at the annual meeting of the American Educational Research Association, Atlanta, GA. 
MEXT. (2005). Gakko kihon chosa (Fundamental survey on schools). Retrieved January 30, 2006, from the World Wide Web:

http://www.mext.go.jp/b_menu/toukei/001/05122201/index.htm.

MEXT. (2006). Gakko hyogiin seido tou oyobi gakko un-ei kyogikai setchi joukyou chousa kekka no gaiyo (An overview of the survey on the situation of the establishment of the school advisor system and school management councils). Shukan Kyoiku Shiryo (Weekly Educational References), 923, 39-45.

Mintzberg, H. (1979). The structuring of organizations: A synthesis of the research. Englewood Cliffs, N. J. : Prentice Hall.

Mojkowske, D. \& Fleming, D. (1988). School-site management: Concepts and approaches. Andover, MA: Regional Laboratory for the Educational improvement of the Northeast and Islands.

Murphy, J. \& Beck, L. G. (1995). School-based management as school reform: Taking stock. California: Corwin Press Inc.

Nippon Kyoiku Shinbun (The Japan Education Press) (August $\left.4^{\text {th }}, 2003\right)$. Gakko yosan no kaizen 7 wari no kocho ga jikkan sezu (70\% of principals do not feel that the school budget is improved). The Japan Education Press. 5.

Nippon Kyoiku Shinbun (The Japan Education Press) (October $\left.3^{\text {th }}, 2005\right)$. Kyoiku-cho $77 \%$ "yosan ga fusoku" (77\% of directors "budget is not enough") The Japan Education Press. 5.

Ogawa, M. (2000). Kyouikugyouseikaikaku no yukue to kongo no kadai (The direction of educational administration reform and the task of the future). In M. Nishio \& M. Ogawa, Chiho bunken kaikaku to kyoiku gyosei: kyoiku iinkai, gakko, chiiki (Decentralized reform and educational administration: Boards of education, schools and communities) (34-52). Tokyo: Gyousei.

Ojima, H. (2001). Gakko hyogiinsei ni yoru sankagata gakko keiei no seido (The participatory form of school administration through the school advisor system). In H. Ojima (Eds.), Chiiki jumin no gakko un-ei eno sankaku (The involvement of community residents in school management) (pp. 22-25). Tokyo: Kyoiku Kaihatsu Kenkyujo.

Sato, H. (May 2000). Gakkou hyougiin wo dou setchi suruka (How to set up school advisors?). Kyoushoku kenshu (Teacher Study and Training), 34-37.

Starrat, R. J. (1996). Transforming Educational Administration: Meaning, community, and excellence. New York: The McGraw-Hill Companies, Inc.

Stevenson, Z. (September 1990). Local school-based management in the District of Columbia public schools: First impressions of pilot sites. Washington DC: District of Columbia Public Schools. (ERIC Document Reproduction Service No. ED 331 188)

Urano, T. (1998). Kouchou to shokuinkaigi no riron: Josetsu no 2 (The theory of principals and teacher councils: Introduction 2). Koukou no Hiroba (High School Square), 30, 47-53.

Weiss, C. H. \& Cambone, J. (1994). Principals, shared decision making, and school reform. Educational Evaluation and Policy Analysis, 16 (3), 287-301.

Wohlstetter, P. \& Bufeit, T. (March 1991). School-based management in big city districts: Are dollars decentralized too? Paper presented at the annual meeting of the American Educational Research Association, Chicago. 
Wohlstetter, P. (September 1995). Getting school-based management right: What works and what doesn't? Phi Delta Kappan, 22-26.

Wood, C. J. (Fall 1984). Participatory decision making: Why doesn't it seem to work? Educational Forum, 49 (1), 55-64.

Jun Hirata is associate professor of Department of Educational Science, Faculty of Education at Hirosaki University. He earned a Ph.D. from the Department of Theory and Policy Studies in Education, Ontario Institute for Studies in Education of the University of Toronto in 2004. His specialization is educational administration in the Canadian and Japanese context. He is in charge of the Secretariat of the Japanese Association for Canadian Education Studies, and an editor of "Studies on Education in Canada" published in Japan. 